\title{
ARTN wt Allele
}

National Cancer Institute

\section{Source}

National Cancer Institute. ARTN wt Allele. NCI Thesaurus. Code C113259.

Human ART N wild-type allele is located within 1p33-p32 and is approximately 4 kb in length. This allele, which encodes artemin protein, is involved in both the morphogenesis of Peyer patches and neuroblast proliferation. 